DOI https://doi.org/10.36059/978-966-397-244-2-2-4

Уразовська О. С.

кандидат юридичних наук, адвокат

Рада адвокатів Одеської області

Національної асоціації адвокатів України

м. Одеса, Україна

\title{
СПАДКУВАННЯ ПРАВА НА ЗЕМЕЛЬНУ ДІЛЯНКУ ЗА ЗАКОНОДАВСТВОМ УКРАЇНИ
}

На практиці у осіб, які успадковують права на земельну ділянку, виникає багато проблем із прийняття та оформлення спадкового майна. Дослідивши теоретичні та практичні проблеми спадкування права на земельну ділянку за законодавством України було сформульовано такі науково-теоретичні висновки та практичні рекомендації, що мають наукову новизну: сформульовано авторське визначення спадкування права на земельну ділянку за законодавством України в об'єктивному $i$ суб'єктивному значенні; сформульовано пропозиції щодо вдосконалення цивільного законодавства в цій сфері з метою вироблення єдиних підходів до вирішення проблемних питань, що виникають у нотаріальній та судовій практиці; встановлено, що, крім права власності на земельну ділянку, спадкуватися можуть $i$ інші речові права (емфітевзис, суперфіцій, сервітут); зроблено висновок, що землі сільськогосподарського призначення не можуть перебувати у власності іноземних громадян навіть якщо спадкування права на земельну ділянку за законодавством України відбулося, коли особа ще була громадянином України.

\section{Вступ}

Підписання та ратифікація Угоди про асоціацію між Україною та ЄС вимагає нового підходу до механізму регулювання відносин у сфері охорони та захисту майнових прав та інтересів приватних осіб. Активізація інтеграційних процесів зумовлює необхідність приділення особливої уваги дослідженню досвіду європейських країн щодо вирішення завдань, які постають перед національною юридичною наукою і практикою задля 
Новітні досягнення та вектори розвитку сучасної юриспруденції

ефективного забезпечення охорони та захисту прав та законних інтересів приватних осіб. Ефективність такої діяльності значною мірою забезпечується врахуванням особливостей як наднаціонального законодавства - законодавства ЄС, так і національного законодавства України, оскільки інтеграційні процеси та адаптація законодавства України до законодавства ЄC не означають повної уніфікації, так як вони не відміняють національної самобутності учасників, у тому числі традицій законодавства України.

Спадкування права на земельну ділянку покликане врегулювати перехід належних людині прав та обов'язків у разі іï смерті. Спадкування відноситься до тих інститутів цивільного права, що почали своє формування за давніх часів історії людства і пройшли довгий шлях еволюції.

Основні поняття спадкового права, в тому числі і спадкування землі, з'явилися ще в римському праві, пізніше вони були відтворені цивільним правом в різних країнах і дотепер лежать в основі спадкового права більшості сучасних правових систем. Отже, спадкування права на земельну ділянку в Україні має базуватися як на загальних засадах цивільно-правових відносин, так і на окремих принципах спадкового права, сформованого ще в Римі. Йдеться про фундаментальні засади переходу майна спадкодавця до його спадкоємців, що складають сам зміст спадкування.

Спадкування (hereditas) - це перехід майна померлої особи до іншої особи (осіб). За допомогою цього інституту забезпечується збереження в цілісності майна померлого і перехід цього майна до правонаступника. Під майном розуміється сукупність прав i обов'язків померлого. Перехід землі померлого (наступництво) до інших осіб можливий за однією із двох правових підстав - за заповітом чи за законом.

Із прийняттям Конституції України 28 червня 1996 p. відбулася переорієнтація суспільних відносин на охорону і захист прав громадян, побудову демократичної, правової держави, що зумовлює необхідність дослідження й аналізу на належному науковому рівні історії становлення й розвитку вітчизняного права. Існує ще ряд проблем, які законодавець має вирішити, щоб українська правова система повністю відповідала світовим стандартам. 
Відродження категорій спадкового права, об'єктом яких виступають земля та нерухомість, в Україні розпочалося 3 прийняттям Земельного Кодексу України (далі - ЗК України) [1], Цивільного Кодексу України (далі - ЦК України) [2] та інших нормативно-правових актів, 3 якими в цивільний обіг повернулось право приватної власності та інші речові права на землю (право довічного користування землею, суперфіцій, емфітевзис, сервітут).

Саме у ЦК України 2003 р. з'являється спеціальна норма, яка регулює спадкування права на земельну ділянку - стаття 1225 «Спадкування права на земельну ділянку» [2]:

1. Право власності на земельну ділянку переходить до спадкоємців на загальних підставах, із збереженням її цільового призначення.

2. До спадкоємців житлового будинку, інших будівель та споруд переходить право власності або право користування земельною ділянкою, на якій вони розміщені.

3. До спадкоємців житлового будинку, інших будівель та споруд переходить право власності або право користування земельною ділянкою, яка необхідна для їх обслуговування, якщо інший ії розмір не визначений заповітом.

Отже, здійснення земельної реформи змінює суть і характер земельних правовідносин, має ключове значення для права власності землі, а отже, як наслідок, і для спадкування права на земельну ділянку.

\section{1. Порядок виникнення і оформлення права на земельну ділянку в наслідок спадкування}

Одним із способів набуття права власності на земельну ділянку є успадкування (стаття 131 ЗК України) [1].

Спадкоємець, який бажає реалізувати право на спадкування, що виникло у нього у зв'язку з відкриттям спадщини, має прийняти спадщину у порядку та у строки, встановлені законом (статті 1268, 1269, 1270 ЦК України) [2].

Прийняття спадщини є одностороннім правочином, оскільки його здійснення залежить виключно від волі спадкоємця. Факт прийняття спадщини одним із спадкоємців породжує правові наслідки лише безпосередньо для даної особи і жодним чином не впливає на юридичне становище інших спадкоємців. 
Правочин про прийняття спадщини $\epsilon$ безумовним та беззастережним. Це означає, що не можна поставити факт прийняття спадщини у залежність від настання або ненастання якої-небудь умови (наприклад, прийняття спадщини одним із спадкоємців за умови, що інші спадкоємці від спадщини відмовляються), рівно як і не допускається часткове прийняття спадщини 3 відмовою від прийняття тієї іiї частини, що залишилася.

Оскільки спадковому правонаступництву притаманна риса універсальності, яка передусім виявляється в легальному понятті спадкування (стаття 1216 ЦК України), а також у визначенні складу спадщини (стаття 1218 ЦК України), прийняття спадкоємцем хоча б частини спадщини свідчить про те, що спадкоємець прийняв її у цілому, незалежно від того, у чому полягає частина, що залишилася, і де вона знаходиться [2]. На превеликий жаль, ЦК України 2004 року, як і ЦК УРСР 1963 року, прямо не відтворює відповідної норми, яка $€$ необхідною для чіткого визначення обсягу спадкової маси, а відтак, у кінцевому підсумку, - для ефективної реалізації спадкоємцями своїх прав. Лише в абзаці першому пункту 208 Інструкції про порядок вчинення нотаріальних дій нотаріусами України зазначено, що прийняття спадщини може мати місце лише щодо всієї спадщини [3]. Бажано було б закріпити аналогічну норму і на рівні закону в ЦК України.

Принцип, згідно з яким прийняття спадщини в частині $\epsilon$ прийняттям спадщини в цілому, отримав відображення i y порядку прийняття спадкоємцем спадщини, яка відкрилася для нього одночасно і за заповітом, і за законом. Якщо спадкоємець, який мав право на спадкування і за заповітом, і за законом, подав заяву про прийняття спадщини за однією з цих підстав, він тим самим висловив свою згоду і на прийняття спадщини за іншою підставою. Оскільки даному спадкоємцеві немає потреби приймати іншу частину спадщини за якимось особливим актом, він вважатиметься таким, що прийняв спадщину в цілому - за обома підставами. Така презумпція існуватиме, якщо тільки цей спадкоємець протягом встановленого статтею 1270 ЦК України строку не заявить про свою відмову від прийняття спадщини за іншою підставою [2].

Якщо спадкоємець постійно проживав разом із спадкодавцем на час відкриття спадщини і не відмовився від прийняття 
Новітні досягнення та вектори розвитку сучасної юриспруденції

спадщини, або спадкоємець на час відкриття спадщини $\epsilon$ малолітнім, неповнолітнім, недієздатним або особою 3 обмеженою цивільною дієздатністю i не відмовився від прийняття спадщини, він вважається таким, що прийняв спадщину автоматично (частини 3, 4 статті 1268 ЦК України) [2]. Природно, що такий спадкоємець прийняв спадщину і за заповітом, і за законом.

Важливою ознакою $є$ те, що до спадкування земельної ділянки не застосовується правило зворотної сили. Право власності на нерухоме майно виникає у спадкоємця не з часу відкриття спадщини, а 3 моменту державної реєстрації цього майна (частина 2 статті 1299 ЦК України) [2]. Прив'язка часу виникнення права власності на успадковане нерухоме майно до моменту державної реєстрації останнього характеризує сучасну законодавчу тенденцію щодо правочинів з нерухомістю: право власності у набувача виникає, а сам правочин вважається вчиненим лише після здійснення його державної реєстрації (частина 1 статті 210, частина 4 статті 334 ЦК України) [2].

Виникає питання, якщо спадкоємець прийняв спадщину, у складі якої є земельна ділянка, але не зареєстрував ії, то, чи вважається він власником цієї земельної ділянки. Однозначної відповіді на це питання законодавець не дає. 3 одної сторони, згідно з частини 3 статті 1296 ЦК України, відсутність свідоцтва не позбавляє спадкоємця права на спадщину, тобто факт отримання (неотримання) свідоцтва про право на спадщину не повинен впливати на обсяг прав та обов'язків спадкоємця. Непрямий висновок щодо універсального правонаступництва спадкоємців, що прийняли спадщину, міститься в пункті 27 постанови Пленуму Верховного Суду України «Про судову практику у справах про спадкування» № 7 від 30.05.2008 р., де зазначено: «Отримання спадкоємцем, який прийняв спадщину, свідоцтва про право на спадщину відповідно до статті 1296 ЦК України є правом, а не обов'язком спадкоємця. Відсутність у спадкоємця свідоцтва про право на спадщину не може бути підставою для відмови у відкритті провадження у справі [4].

Значна кількість дискусій виникає під час оформлення спадщини на земельні ділянки, що пов'язане з відсутністю прямого правового регулювання спадкування даного виду майна в ЦК України. Першою особливістю спадкування земельної ділянки $\epsilon$ те, що чинне законодавство обумовлює обов'язком 
Новітні досягнення та вектори розвитку сучасної юриспруденції

збереження ії цільового призначення. Цільове ж призначення земельної ділянки визначається в державному акті на право власності на землю.

Процес оформлення спадкових прав на земельну ділянку має свої особливості. Правове оформлення спадкових прав являє собою сукупність правових дій, після вчинення яких установлюється частка кожного спадкоємця у спадковому майні, і спадкоємці набувають права розпоряджатися цим майном [5].

Для оформлення спадкових прав на земельну ділянку необхідно:

1. Прийняти спадок.

Спадкоємець за законом чи за заповітом має право прийняти спадщину, або не прийняти ії (стаття 1268 ЦК України) [2]. Для цих осіб створюється лише можливість вступити у спадкові правовідносини. А реалізуватися вона може через подання до державної нотаріальної контори за місцем відкриття спадщини заяви про її прийняття, протягом шести місяців з часу відкриття спадщини. Прийняття спадщини - це вольовий акт, в якому знаходить своє вираження бажання спадкоємця прийняти спадщину [5, с. 63-68].

2. Надати нотаріусу документи для підтвердження прав спадкоємця.

Перелік документів, необхідних для спадкування, для отримання свідоцтва про право на спадщину: паспорт; довідка про присвоєння ідентифікаційного номера; свідоцтво про смерть спадкодавця; заява про прийняття спадщини (подається до 6 місяців з дня смерті спадкодавця); довідка, що підтверджує факт прийняття спадщини шляхом спільного проживання зі спадкодавцем (за відсутності заяви про прийняття спадщини); довідка про останнє місце реєстрації та проживання померлої особи; заповіт (для спадкування за заповітом); документи, що підтверджують і визначають ступінь родинних відносин між спадкодавцем і спадкоємцем (для спадкування за законом).

3. Складання нотаріусом запитів стосовно спадкування земельної ділянки.

Крім вищеназваних документів для спадкування земельної ділянки необхідно: документ, що підтверджує право власності на земельну ділянку(договір купівлі-продажу(дарування) i/або державний акт про право власності на земельну ділянку); витяг 3 бази даних автоматизованої системи ведення державного 
земельного кадастру про відсутність обмежень та обтяжень на земельну ділянку; нормативно-грошова оцінка земельної ділянки з відділу земельних ресурсів. Для спадкування земельної частки (паю): сертифікат на право на земельну частку (пай); виписка з членів КСП; нормативно-грошова оцінка земельного паю на дату смерті спадкодавця.

Нотаріус при оформленні спадщини шляхом витребування відповідних доказів має перевірити певні факти, зокрема, визначити склад спадкового майна, на яке видається свідоцтво. Свідоцтво про право на спадщину не створює ніяких нових прав у спадкоємців на майно, а тільки підтверджує вже існуюче право на нього, бо право на спадкування в них виникає 3 моменту відкриття спадщини.

Свідоцтво про право на спадщину - це спеціальний документ, що видається на ім'я всіх спадкоємців разом або, за їхнім бажанням, кожному окремо [5, с. 418]. Одержання свідоцтва про право на спадщину є загальним порядком оформлення спадкових прав. Видача свідоцтва про право на спадщину на майно, яке підлягає реєстрації (у тому числі земельна ділянка), провадиться нотаріусом після подання правовстановлюючих документів, які підтверджують право власності спадкодавця на таке майно.

На сьогодні, відповідно до положень ЗК України, до документів, що посвідчують право власності на земельну ділянку, належать державний акт про право власності на земельну ділянку, цивільно-правова угода щодо відчуження земельної ділянки, укладена в порядку, встановленому законом (договір купівлі-продажу, дарування, довічного утримання тощо), а також свідоцтво про право на спадщину [1]. При цьому, у тому випадку, коли право власності на земельну ділянку посвідчується відповідною цивільно-правовою угодою чи свідоцтвом про право на спадщину, такі документи не $\epsilon$ самостійними правовстановлюючими документами, оскільки до них в якості додатка має бути долучений державний акт про право власності на земельну ділянку, що була відчужена чи успадкована.

Крім того, на долученому державному акті повинна міститись відмітка нотаріуса, яким було посвідчено відповідний договір чи видано свідоцтво, а також органу, який здійснює державну реєстрацію прав на нерухоме майно, про перехід права власності на земельну ділянку. 
Новітні досягнення та вектори розвитку сучасної юриспруденції

Окремо слід розглянути питання щодо оформлення спадкових прав на земельну ділянку іноземними громадянами та особами без громадянства.

Оформлення такими особами спадкових прав на земельні ділянки здійснюється за загальними правилами, передбаченими чинним цивільним законодавством. У порядку спадкування право власності на земельну ділянку всіх категорій земель можуть набувати всі суб'єкти земельних правовідносин, в тому числі і іноземні громадяни і особи без громадянства. Однак, ЗК України встановлено обов'язок іноземного громадянина або особи без громадянства, що прийняли у спадщину земельну ділянку сільськогосподарського призначення, протягом року відчужити таку земельну ділянку. Невиконання зазначеної вимоги $\epsilon$ підставою для примусового припинення прав на земельну ділянку, що здійснюється у судовому порядку (стаття 140 ЗК України) [1]. Оскільки ж землі сільськогосподарського призначення не можуть передаватись у власність іноземцям, слід визнати, що видача свідоцтва про право на спадщину нотаріусом не грунтується на законі. Виникає колізія норм, одна з яких допускає прийняття сільськогосподарських земель у спадщину (частина 4 статті 81 ЗК України) [1], а інші не допускають виникнення права власності на ці ділянки (частина 2 статті 81, частина 2 статті 82 ЦК України) [2].

3 моменту отримання витягу з Державного реєстру речових прав на нерухоме майно, спадщина на земельну ділянку може вважатись оформленою належним чином. Вказаний витяг $\epsilon$ остаточним документом, який підтверджує право власності на успадковану земельну ділянку [7, с. 11-13].

Якщо спадкоємець із якихось причин пропустив 6-місячний строк для прийняття спадщини, може виникнути необхідність включення його до числа спадкоємців, а, отже, і внесення змін до свідоцтва про право на спадщину. Це можливе за письмовою згодою всіх спадкоємців, які прийняли спадщину. Якщо такої згоди немає, то спадкоємець, який пропустив строк для прийняття спадщини, може звернутися до суду із заявою про внесення змін до свідоцтва про право на спадщину.

Якщо суд знайде причини пропуску строку поважними i задовольнить позов, але спадкове майно вже було прийняте іншими спадкоємцями, то спадкоємець, який пропустив строк, 
одержить лише майно, що збереглося в натурі, а також кошти, виручені від реалізації решти належного йому майна.

у деяких випадках можлива видача додаткового свідоцтва про право на спадщину. Необхідність у ньому виникає, коли спадкоємці одержали свідоцтво на певну частину майна, а пізніше було виявлене інше майно, не зазначене у виданому свідоцтві.

Свідоцтво про право на спадщину може бути визнано недійсним за рішенням суду у випадках порушення правил, встановлених нормами книги 6 ЦК України, а також нормами глави 16 ЦК України [2].

31 січня 2016 року набрав чинності Закон України від 20.10 .2014 p. № 1709-VII «Про внесення змін до деяких законодавчих актів щодо деяких питань спадкування» [8]. Законом спрощено процедуру оформлення спадщини та реєстрації прав спадкоємців на успадковане ними нерухоме майно (насамперед, у сільських населених пунктах) шляхом надання відповідних повноважень органам місцевого самоврядування.

Крім цього, законом також скасовується обов'язкове проведення оцінки майна у випадках спадкування майна спадкоємцями першої та другої черги за законом та за правом представлення, а також у випадку спадкування спадщини, яка оподатковується за нульовою ставкою податку.

Зазначеним законом повноваження нотаріуса в сільських населених пунктах покладаються на уповноважену на це посадову особу відповідного органу місцевого самоврядування. Відповідно до статті 37 Закону України «Про нотаріат» уповноважені посадові особи органу місцевого самоврядування, це особи, які мають вищу юридичну освіту, досвід роботи у галузі права не менше трьох років, пройшли протягом року стажування у державній нотаріальній конторі або приватного нотаріуса, завершили навчання щодо роботи 3 єдиними та державними реєстрами, що функціонують в системі Міністерства юстиції України, та склали іспит із спадкового права у порядку, встановленому Міністерством юстиції України [9].

Згідно зі статтею 9 Закон України «Про державну реєстрацію речових прав на нерухоме майно та їх обтяжень» (в редакції від 06.10.2021 р.) посадова особа органу місцевого самоврядування сільського населеного пункту як спеціальний суб'єкт здійснює функції державного реєстратора щодо реєстрації прав 
спадкоємців першої та другої черги за законом (як у випадку спадкування ними за законом, так і у випадку спадкування ними за заповітом) і за правом представлення на успадковане ними нерухоме майно, а також щодо реєстрації прав власності на частку у спільному майні подружжя в разі смерті одного із подружжя [10].

Свідоцтво про право на спадщину видається після закінчення шести місяців з дня відкриття спадщини, а у випадках, передбачених частиною другою статті 1270 і статтею 1276 ЦК України, - не раніше зазначених у цих статтях строків [2]. Видача свідоцтва про право на спадщину спадкоємцям, які прийняли спадщину, строком не обмежена.

Отже, закон покликаний спростити процедуру оформлення спадщини та реєстрації прав спадкоємців на успадковане ними нерухоме майно (насамперед, у сільських населених пунктах).

В Україні напрацьована судова практика з оформлення права на земельну ділянку внаслідок спадкування. Судова палата у цивільних справах Верховного Суду України розглянула справу про визнання права на спадщину (Постанова від 23 листопада 2016 року № 6-3113цс15) [11], дана правова позиція суду $\epsilon$ важливою для практики з цього питання. Позивачка звернулася до суду, посилаючись на неможливість оформити спадщину після смерті чоловіка через відсутність правовстановлюючих документів на майно фермерського господарства як цілісного майнового комплексу. Суд першої інстанції позов задовольнив, виходячи 3 того, що фермерське господарство $\epsilon$ цілісним майновим комплексом відповідно до вимог статті 22 Закону України «Про фермерське господарство» [12], а тому підлягає спадкуванню разом із земельною ділянкою, на якій воно створено, яка також входить до складу спадкових прав. Однак апеляційний суд, з висновками якого погодився й суд касаційної інстанції, скасував попереднє судове рішення на підставі того, що законом передбачено лише договірний порядок установлення емфітевзису, проте такого договору не існувало, спадкодавець за життя не переоформив у встановленому законом порядку надане йому право постійного користування земельною ділянкою або право оренди, а тому відсутні підстави для задоволення позовних вимог про визнання права спадщини на право постійного користування земельною ділянкою за позивачем. У свою чергу, Верховний Суд України підтримав рішення 
апеляційного та касаційного судів, висловивши таку правову позицію. За змістом положень статті 182 ЦК України до складу спадщини входить лише те нерухоме майно, право на яке зареєстровано в органах, що здійснюють державну реєстрацію нерухомого майна. Таким чином, видача свідоцтва про право на спадщину на майно, яке підлягає державній реєстрації, провадиться після подання правовстановлюючих документів про належність цього майна спадкодавцеві. Згідно 3 частиною 1 статті 92 ЗК України (у редакції чинній на час виникнення спірних відносин) право постійного користування земельною ділянкою - це право володіння і користування земельною ділянкою, яка перебуває у державній або комунальній власності, без встановленого строку. Зі змісту частини другої статті 92 ЗК України вбачається, що передача земельної ділянки у постійне користування громадянам не передбачена. Пунктом 6 Перехідних положень ЗК України визначено, що громадяни та юридичні особи, які мають у постійному користуванні земельні ділянки, але за цим Кодексом не можуть мати їх на такому праві, повинні до 1 січня 2008 року переоформити у встановленому порядку право власності або право оренди на них.

Отже, земельні ділянки, надані громадянам або юридичним особам у постійне користування, перебувають у власності держави або у власності територіальної громади до переоформлення у встановленому порядку та отримання у власність чи користування. Відповідно до частини першої статті 125 ЗК України (в редакції, чинній на час виникнення спірних правовідносин) право власності та право постійного користування на земельну ділянку виникає після одержання іï власником або користувачем документа, що посвідчує право власності чи право постійного користування земельною ділянкою, та його державної реєстрації. Згідно із частиною першою статті 126 ЗК України право власності на земельну ділянку посвідчується державним актом, крім випадків, визначених частиною другою цієї статті. Відповідно до статті 131 ЗК України громадяни та юридичні особи України, а також територіальні громади та держава мають право набувати у власність земельні ділянки на підставі міни, ренти, дарування, успадкування та інших цивільно-правових угод. Укладення таких угод здійснюється відповідно до ЦК України з урахуванням вимог цього Кодексу [2]. 
Згідно з частиною першою статті 407 ЦК України право користування чужою земельною ділянкою встановлюється договором між власником земельної ділянки і особою, яка виявила бажання користуватися цією земельною ділянкою для сільськогосподарських потреб. Відповідно до частини другої статті 407 ЦК України (у редакції, що діяла на час відкриття спадщини), та частини другої статті 1021 ЗК України право користування чужою земельною ділянкою для сільськогосподарських потреб (емфітевзис) може відчужуватися i передаватися у порядку спадкування. Відповідно до статті 1225 ЦК України право власності на земельну ділянку переходить до спадкоємців за загальними правилами спадкування (зі збереженням ії цільового призначення) при підтвердженні цього права спадкодавця державним актом на право власності на землю або іншим правовстановлюючим документом. У порядку спадкування можуть передаватися також право користування земельною ділянкою для сільськогосподарських потреб (емфітевзис), право користування чужою земельною ділянкою для забудови (суперфіцій), право користування чужим майном (сервітут). Відповідно до статті 1216 ЦК України спадкуванням $\epsilon$ перехід прав та обов'язків (спадщини) від фізичної особи, яка померла (спадкодавця), до інших осіб (спадкоємців). Згідно статті 1218 ЦК України до складу спадщини входять усі права та обов'язки, що належали спадкодавцеві на момент відкриття спадщини і не припинилися внаслідок його смерті. Аналіз зазначених норм свідчить про те, що право користування земельною ділянкою, що виникло в особи лише на підставі державного акта на право користування земельною ділянкою без укладення договору про право користування земельною ділянкою із власником землі, припиняється зі смертю особи, якій належало таке право і не входить до складу спадщини.

Починаючи з 1 січня 2013 року в Україні істотно змінилися правила державної реєстрації прав на нерухоме майно i, в тому числі, земельні ділянки. Автоматично відомості із Державного земельного кадастру до новоствореного Державного реєстру речових прав на нерухоме майно не переносяться, а тому для власників земельних ділянок може виникнути потреба у перереєстрації свого права. Раніше права на землю реєструвалися державними органами земельних ресурсів із присвоєнням ділянці кадастрового номеру та видачею 
Новітні досягнення та вектори розвитку сучасної юриспруденції

державного акту на право приватної власності на землю. Починаючи з 2013 року цей порядок реєстрації вже не застосовується. Відтепер реєстрацією прав опікується Державна реєстраційна служба, а на підтвердження державної реєстрації права видається не державний акт, а витяг з Державного реєстру прав на нерухоме майно та їх обтяжень.

Судами залишено без задоволення позовні вимоги особи до державного нотаріуса щодо відмови у вчиненні нотаріальної дії, а саме: Особа звернулася до суду для захисту своїх прав та просила визнати незаконною відмову у вчиненні нотаріальної дії, зобов'язати державного нотаріуса видати свідоцтво про право на спадщину їй та її дітям. Позивач посилалась на те, що після смерті чоловіка за місцем реєстрації в Луганській області було відкрито спадкову справу, однак вона не могла отримати свідоцтво про право на спадщину у зв'язку з проведенням антитерористичної операції. Після чого особа звернулась до державного нотаріуса державної нотаріальної контори Київської області, але отримала відмову у видачі свідоцтва про право на спадщину.

Відповідно до статті 50 Закону України «Про нотаріат» нотаріальна дія або відмова у ії вчиненні, нотаріальний акт оскаржуються до суду. Право на оскарження нотаріальної дії або відмови у її вчиненні, нотаріального акта має особа, прав та інтересів якої стосуються такі дії чи акти [9].

Розглядаючи справу, судами встановлено законність дій нотаріуса.

Відповідно до статті 1220 ЦК України спадщина відкривається внаслідок смерті особи або оголошення її померлою. Згідно зі статтею 1221 ЦК України місцем відкриття спадщини є останнє місце проживання спадкодавця [2].

Відповідно до статті 11-1 Закону України «Про забезпечення прав і свобод громадян та правовий режим на тимчасово окупованій території України» № 1207-VII від 15.04.2014 у разі якщо останнім місцем проживання спадкодавця $\epsilon$ тимчасово окупована територія, місцем відкриття спадщини $є$ місце подання першої заяви, що свідчить про волевиявлення щодо спадкового майна, спадкоємців, виконавців заповіту, осіб, заінтересованих в охороні спадкового майна, або вимоги кредиторів [13]. 
Отже, можна зробити висновок про те, що спадкоємець, який бажає реалізувати право на спадкування, що виникло у нього у зв'язку з відкриттям спадщини, має прийняти спадщину у порядку та у строки, встановлені законом. Право на отримання земельної ділянки у спадщину виникає лише за умови виникнення права власності на цю землю у спадкодавця. Для оформлення спадкових прав на земельну ділянку необхідно: прийняти спадок; надати нотаріусу документи для підтвердження прав спадкоємця; складання нотаріусом запитів стосовно спадкування земельної ділянки.

\section{2. Основні проблеми, які виникають при спадкуванні права на земельну ділянку за законодавством України та шляхи їх вирішення}

Правове оформлення спадкових прав являє собою сукупність правових дій, після вчинення яких встановлюється частка кожного спадкоємця в спадковому майні, і спадкоємці набувають право розпоряджатися цим майном [5].

На практиці у осіб, які успадковують земельну ділянку, виникає багато проблем з прийняття та оформлення спадкового майна.

Часто трапляється так, що земельна ділянка з однієї сторони належала спадкодавцю на праві власності на підставі державного акту. Але в той же час в Держаному земельному кадастрі відсутні відомості щодо присвоєння такій земельній ділянці кадастрового номеру. В цьому випадку процес оформлення спадщини на земельну ділянку уповільнюється необхідністю організації дій щодо внесення земельної ділянки до бази Державного земельного кадастру та отримання відповідного витяг 3 кадастру. З 10.12.2009 року набрав чинності Закон України «Про внесення змін до деяких законодавчих актів України щодо спрощення порядку набуття прав на землю». Частиною 2-ою статті 377 ЦК України встановлено, що розмір та кадастровий номер земельної ділянки, право на яку переходить у зв'язку з переходом права власності на житловий будинок, будівлю або споруду, $є$ істотними умовами договору, який передбачає набуття права власності на ці об’єкти (крім багатоквартирних будинків) [2].

Відповідно до пунктів 1.5, 5.1 Порядку присвоєння кадастрових номерів земельним ділянкам, затвердженого наказом Державного комітету України із земельних ресурсів від 
15.02.2010 року № 168, кадастрові номери присвоюються усім земельним ділянкам незалежно від форм власності.

Формування кадастрових номерів земельних ділянок, які на момент набрання чинності цим наказом надані у власність (користування) та не мають кадастрових номерів, здійснюються територіальними органами Держкомзему.

Отримати витяг 3 кадастру на земельну ділянку, яка не має кадастрового номеру, можна звернувшись до землевпорядної організації, яка має в своєму штаті сертифікованих інженерівземлевпорядників. Землевпорядна організація розробить технічну документацію щодо встановлення меж земельної ділянки в натурі (на місцевості), погодить її у необхідних установах та отримає витяг з кадастру, який в подальшому треба буде подати нотаріусу для прийняття спадщини на земельну ділянку (технічна документація щодо встановлення меж земельної ділянки розробляється на ім'я спадкодавця, а сам витяг $з$ кадастру видається на ім'я спадкоємця, що зазначений в запиті нотаріуса).

Існують випадки, коли спадкоємцям відмовляють у видачі свідоцтва про право на спадщину на земельну ділянку, оскільки він не може надати оригінал державного акта на право власності на земельну ділянку, виданого на ім'я спадкодавця. Якщо проблема лише у його втраті, то слід отримати дублікат державного акта, для чого потрібно письмово звернутись до органу який його видав.

Можуть виникнути процедурні питання за наявності кількох спадкоємців на одну земельну ділянку. Так, статті 86-89 3К України визначають, що земельна ділянка може знаходитись у спільній власності, або у спільній сумісній власності, або у спільній частковій власності [1]. Суб'єктами права спільної власності на землю можуть бути громадяни та юридичні особи. Однією 3 підстав для виникнення права спільної часткової власності $\epsilon$ прийняття спадщини на земельну ділянку двома або більше особами. При цьому, частка у спільній сумісній власності спадкується на загальних підставах.

У нормах ЗК України залишається невизначеним питання стосовно розпорядження земельними ділянками сільськогосподарського призначення особами, які отримали у власність ці ділянки за часів перебування в громадянстві України, а згодом змінили громадянство. Крім того, законодавством не визначений 
порядок відчуження такої земельної ділянки. Відчуження успадкованої земельної ділянки сільськогосподарського призначення повинно реалізуватися шляхом укладення іноземним громадянином чи особою без громадянства будь-якої цивільно-правової угоди, що передбачена цивільним чи земельним законодавством України, та відповідно до якої здійснюватиметься перехід права власності на земельну ділянку до іншої особи. До тих пір, поки з цього питання буде прогалина в законодавстві, на практиці ми повинні діяти за аналогією 3 процедурою прийняття та оформлення спадщини іноземними особами або особами без громадянства. Тобто, після того, як особа перестала бути громадянином України, вона повинна відчужити землю сільськогосподарського призначення.

Проблемою $є$ відсутність певних документів для оформлення права на спадщину. Вирішення цієї проблеми можливо двома шляхами.

Перший. п. 4.18 Порядку вчинення нотаріальних дій нотаріусами України встановлює, що за відсутності у спадкоємця необхідних для видачі свідоцтва про право на спадщину документів нотаріус роз'яснює йому процедуру вирішення зазначеного питання в судовому порядку. У листі Вищого Спеціалізованого Суду України 3 розгляду цивільних та кримінальних справ від 16.05.2013 № 24-753/0/4-13 зазначено, що [14]: «відповідачами у справах про визнання права власності в порядку спадкування на будинки та садиби, щодо яких відсутні правовстановлюючі документи у зв'язку 3 їх втратою, $\epsilon$ спадкоємці, які прийняли спадщину, а також органи, які уповноважені видавати правовстановлюючі документи на нерухоме майно, або ж органи, до яких перейшли такі повноваження, та органи, що здійснюють державну реєстрацію прав на нерухоме майно». Тобто це означає, що потрібно буде звернутися до суду із позовною заявою до спадкоємців, які вже отримали свідоцтво про право на спадщину, адже це означає, що у них є потрібні документи. Якщо ж у них таких документів немає, то відповідачем у справі буде орган, що може видати потрібний позивачу документ.

Але можна у судовому порядку одразу і вирішити питання про визнання права на спадщину, а не просто отримати потрібний документ. У вищезазначеному листі наведено приклад. 
Також має місце і другий випадок: якщо документи, що засвідчують право власності на нерухоме майно, існували, проте були втрачені власником та не можуть бути відновлені в передбаченому законом порядку. Застосуванню підлягає стаття 392 ЦК України, відповідно до якої позов про визнання права власності може бути пред'явлений, якщо це право оскаржується або не визнається іншою особою, а також у разі втрати власником документа, який засвідчує його право власності [2]. Це означає, що позови про визнання за спадкодавцем права власності на майно також можуть бути задоволені судом за наявності належних доказів.

у вище зазначеному Листі вказано, що «якщо виникнення права на спадкування залежить від доведення певних фактів, особа може звернутися в суд із заявою про встановлення цих фактів, яка, у разі відсутності спору, розглядається за правилами окремого провадження. Зокрема, у такому порядку суди повинні розглядати заяви про встановлення родинних відносин із спадкодавцем, проживання 3 ним однією сім'єю, постійного проживання разом зі спадкодавцем на час відкриття спадщини, факту прийняття спадщини відповідно до статті 549 ЦК України».

Ситуація, що розглядається, стосується питання оформлення права на успадковане нерухоме майно, право власності на яке не було зареєстровано належним чином спадкодавцем.

Ситуація ця $\epsilon$ доволі поширеною, особливо у сфері земельних відносин. Все-таки порядок оформлення прав на житлові/нежитлові приміщення $\epsilon$ не таким витратним за часом i часто спадкодавці оформлюють такі права у незначні строки. Водночас процедура оформлення права на земельну ділянку протягом значного часу була значно більш складною та витратною за часом.

Доволі зрозумілим $є$ порядок оформлення права власності на ділянку, на якій знаходиться будинок, права на який вже оформлено. У цьому випадку потрібно подавати позов на підставі статті 1225 ЦК України. За приписами цієї статті право власності на земельну ділянку переходить до спадкоємців на загальних підставах, із збереженням іï цільового призначення. До спадкоємців житлового будинку, інших будівель та споруд переходить право власності або право користування земельною ділянкою, на якій вони розміщені. 
Новітні досягнення та вектори розвитку сучасної юриспруденції

Отже, у даному випадку як правило позов заявляється до органу місцевого самоврядування, при цьому у якості співвідповідача, або третьої особи зазначається місцевий відділ земельних ресурсів.

Позовні вимоги заявляються щодо визнання права власності на земельну ділянку за особою.

Зрозуміло, що всі сторони процесу розуміють навіщо взагалі подається позов і як правило, представники органу місцевого самоврядування та відділу земельних ресурсів не заперечують проти задоволення позовних вимог. Лояльно, зазвичай, до таких вимог відноситься і суд, тому практика по задоволенню подібних позовних заяв $є$ дуже поширеною.

Складнішим $\epsilon$ варіант, якщо ділянка знаходиться $у$ співвласності декількох осіб.

Якщо мова йде про спільну часткову власність, то питання вирішується нескладно - позовні вимоги заявляються до співвласника земельної ділянки, який нібито «не визнає» права спадкоємця.

Знову ж таки у даному випадку, якщо немає конфліктів із співвласником - то все вирішується просто - співвласник у судовому засіданні підтримує позовні вимоги, суд на підставі цього, а також на підставі доводів, що застосовуються у першому випадку приймає рішення про визнання права власності на визначену частину ділянки.

Отже, у більшості спірних ситуацій єдині підходи до їх розв'язання не вироблені в даний час ні нотаріальної, ні судовою практикою. Відповідно, необхідне серйозне теоретичне дослідження проблем цивільно-правового статусу земельних ділянок та речових прав на них у контексті спадкування як за законом, так і за заповітом.

Хоча Закон України «Про державну реєстрацію речових прав на нерухоме майно та їх обтяжень» і визнає всі права на земельні ділянки, які були зареєстровані до 1 січня 2013 р., однак у власників земельних ділянок та їх спадкоємців можуть виникнути проблеми у разі, якщо така ділянка не має кадастрового номера [10]. Чинним законодавством встановлена форма витягу 3 Державного земельного кадастру (додаток № 47 до Порядку ведення Державного земельного кадастру, затвердженого постановою Кабінету Міністрів України від 17 жовтня 2012 р. № 1051), витяг містить усі відомості про земельну ділянку, внесені 
до Поземельної книги, у ньому ж повинен бути зазначений кадастровий номер земельної ділянки. За такої ситуації нотаріус буде вимушений, керуючись нормативно встановленими вимогами, відмовляти у видачі свідоцтва про право на спадщину на земельну ділянку, щодо якої відсутній кадастровий номер. На наш погляд таке рішення $є$ безпідставним, оскільки кадастровий номер має здебільшого облікове, а не правовстановлююче значення щодо земельної ділянки. Слід також звернути увагу й на наступне положення Закону України «Про Державний земельний кадастр» [15]: якщо на земельній ділянці, право власності (користування) на яку не зареєстровано, розташований житловий будинок, право власності на який зареєстровано, кадастровий номер на таку земельну ділянку присвоюється за заявою власників такого будинку на підставі технічної документації із землеустрою щодо встановлення (відновлення) меж земельної ділянки в натурі (на місцевості). Норма досить складна для практичного застосування, зокрема у ситуації, коли фактичні обставини повною мірою відповідають її змісту, але власник помер. Вважаємо, що у такій ситуації спадкоємці, які прийняли спадщину, відповідно до правил частини 5 статті 1268 ЦК України вправі звернутись із заявою про присвоєння кадастрового номера. Тобто дану норму слід застосовувати із розширювальним тлумаченням, маючи на увазі не тільки власників, а й спадкоємців, які прийняли спадщину [16].

Не менш суперечливою $€$ ситуація із спадкоємцями, які постійно проживали разом зі спадкодавцем. Згідно 3 положеннями частини 3 статті 1268, статті 1269 ЦК України [2], спадкоємець, який постійно проживав разом із спадкодавцем на час відкриття спадщини, вважається таким, що прийняв спадщину, якщо протягом строку, встановленого статтею 1270 цього Кодексу, він не заявив про відмову від неї. Спадкоємець, який бажає прийняти спадщину, але на час відкриття спадщини не проживав постійно із спадкодавцем, має подати нотаріусу заяву про прийняття спадщини. Слід зауважити, що згідно 3 п. 4.10 гл. 10 «Порядку вчинення нотаріальних дій нотаріусами України», затвердженого наказом Міністерства Юстиції України № 296/5 від 22.02.2012 р. [17], видача свідоцтва про право на спадщину спадкоємцям, які прийняли спадщину, ніяким строком не обмежена. Натомість на нотаріусів не покладений обов'язок за своєю ініціативою встановлювати коло спадкоємців, тобто якщо 
до нотаріуса звернувся спадкоємець із заявою про прийняття спадщини, то у такому випадку нотаріус повинен видати йому свідоцтво про право на спадщину, у тому числі - на нерухоме майно, після чого цей спадкоємець вправі на законній підставі укласти правочин з відчуження такого майна. Однак після цього може скластися вкрай неприємна ситуація, якщо до нотаріуса за отриманням свідоцтва звернеться ще один спадкоємець, який постійно проживав разом із спадкодавцем - тобто виявиться, що спадкоємців вже більше одного. Виникне судовий спір, в результаті якого буде встановлена часткова (а не одноособова) власність на спадкове майно, і «новий» спадкоємець буде вправі витребувати свою частку майна у добросовісного набувача, якій придбав це майно у «старого» спадкоємця.

Але у цих випадках щонайменше існує право вибору приймати спадщину чи відмовлятись від неї, реєструвати успадковане нерухоме майно чи не реєструвати, укладати 3 таким майном угоди, чи краще утриматись від цього. Але $\epsilon$ випадки, коли особа навіть не має права вибору, стаючи заручником недосконалого законодавства. Згідно з частиною 3 , частиною 4 статті 1273 ЦК України, неповнолітня особа віком від чотирнадцяти до вісімнадцяти років може відмовитися від прийняття спадщини за згодою батьків (усиновлювачів), піклувальника i органу опіки та піклування [2]. Батьки (усиновлювачі), опікун можуть відмовитися від прийняття спадщини, належної малолітній, недієздатній особі, лише 3 дозволу органу опіки та піклування. Як відомо, у нас діють популістські традиції та звичаї, які вважаються направленими на соціальний захист прав дітей на майно, тобто практично неможливо отримати згоду органу опіки та піклування на відмову від спадщини малолітньою (неповнолітньою) особою.

Автор погоджується з думко Є. Осичнюка, що законодавство у цій галузі потребує реформування. Необхідно вдосконалити процедуру оформлення спадщини. Заяву про прийняття спадщини повинні подавати всі спадкоємці, незалежно від факту спільного із спадкодавцем проживання. Це одночасно вирішить проблему «примусового спадкування» неповнолітніми особами. Необхідно впровадити можливість реєстрації права власності на нерухоме майно за спадкоємцями на підставі відповідної ухвали суду, що розглядає справу за позовом кредиторів до спадкоємців боржника, або подання про заміну сторони виконавчого провадження. Також, 
необхідно законодавчо обмежити можливість встановлення будьяких додаткових строків на прийняття спадщини, тому що існуюча ситуація правової невизначеності порушує права третіх осіб (наприклад, добросовісних набувачів майна, що відчужується спадкоємцями) [18].

\section{Висновки}

У Висновках викладено найбільш вагомі наукові результати дослідження, до яких належать такі:

1. Спадкування права на земельну ділянку за законодавством України слід розуміти в об'єктивному і суб'єктивному значенні. В об'єктивному значенні воно являє собою сукупність норм, що регулюють відносини 3 приводу переходу прав і обов'язків померлого громадянина до інших осіб. У суб'єктивному значенні під правом успадкування розуміється можливість особи бути покликаною до спадкоємства, а також її правомочності після прийняття спадщини.

2. Правове оформлення спадкових прав являє собою сукупність правових дій, після вчинення яких установлюється частка кожного спадкоємця у спадковому майні, і спадкоємці набувають права розпоряджатися цим майном. 3 моменту отримання витягу 3 Державного реєстру речових прав на нерухоме майно, спадщина на земельну ділянку може вважатись оформленою належним чином. Вказаний витяг $€$ остаточним документом, який підтверджує право власності на успадковану земельну ділянку.

3. У порядку спадкування можуть передаватися також право користування земельною ділянкою для сільськогосподарських потреб (емфітевзис), право користування чужою земельною ділянкою для забудови (суперфіцій), право користування чужим майном (сервітут). У зв'язку з чим необхідно доповнити статтю 1225 ЦК України відповідними положеннями.

4. Виділено основні проблеми, що виникають при спадкуванні права на земельну ділянку за законодавством України, та запропоновано шляхи їх вирішення:

1) спадкоємець не має оригіналу Державного акту на право власності на земельну ділянку, виданого на ім'я спадкодавця. Якщо проблема лише у втраті Державного акту, то слід отримати його дублікат, для чого потрібно письмово звернутись до органу, який його видав; 
2) розпорядження земельними ділянками сільськогосподарського призначення особами, які отримали у власність ці ділянки за часів перебування в громадянстві України, а згодом змінили громадянство. Відчуження такої земельної ділянки повинно реалізуватися шляхом укладення іноземним громадянином чи особою без громадянства будь-якої цивільноправової угоди, що передбачена цивільним чи земельним законодавством України, відповідно до якої здійснюватиметься перехід права власності на земельну ділянку до іншої особи (громадянина України);

3) коли землю спадкодавець заповів одному спадкоємцю, а розташований на ній будинок - іншому. Таким чином порушується право спадкоємця, якому залишена земля в спадок, бо нерухомість розташована на ній $\epsilon$ неподільною із земельною ділянкою, i земля переходить все рівно в спадок тому спадкоємцю, котрому за заповітом переходить будинок;

4) спадкування права на земельну ділянку, яка $\epsilon$ майном члена фермерського господарства. Встановлено, що без державної реєстрації підприємства як цілісного майнового комплексу ні відчуження, ні спадкування цілісного майнового комплексу не можливе;

5) якщо житловий будинок, який належав на праві власності померлому громадянину, розташований на неприватизованій земельній ділянці, така земельна ділянка не може бути успадкована - спадкоємці повинні оформити своє право на земельну ділянку, на якій розміщено успадкований житловий будинок. Таке право може бути оформлено шляхом звернення спадкоємців до місцевої ради, яка відповідно до їх заяви має прийняти рішення або про безоплатну передачу у приватну власність цієї земельної ділянки без зміни цільового призначення, або ж про передачу в оренду чи право користування.

\section{Література:}

1. Земельний кодекс України від 25.10.2001 р., № 2768-III. Відомості Верховної Ради України. 2002. № 3-4. Ст. 27. [Електронний peсурс]. - Режим доступу: http://www.zakon.rada.gov.ua/laws/ show/2768-14, вільний.

2. Цивільний кодекс України від 16 січня 2003 року. Відомості Верховної Ради України. 2003. №№ 40-44. Ст. 356. 
3. Інструкція про порядок вчинення нотаріальних дій нотаріусами України: затверджена наказом Міністерства юстиції України від 3 березня 2004 року № 20/5. [Електронний ресурс]. Режим доступу: http://www.zakon.rada.gov.ua/laws/show/z028304, вільний.

4. Про судову практику у справах про спадкування: Постанова Пленуму Верховного Суду України від 30.05.2008 № 7: [Електронний pecypc]. - Режим доступу: http:// www.zakon.rada.gov.ua/laws/show/v0007700-08, вільний.

5. Підопригора О.А., Харитонов Є.О. Римське право: Підручник. 2-ге вид. Київ: Юрінком Інтер, 2009. 528 с.

6. Белянська М.В. Спадкування земельних ділянок громадянами України: процедура, особливості, законодавчі проблеми. Актуальні проблеми політики: зб. наук. праць. 2008. Вип. 35. С. 63-68.

7. Кальніченко А. Новий порядок набуття прав на земельні ділянки та розміщення на них нерухомого майна. Землевпорядний вісник. 2011. № 12. С. 11-13.

8. Про внесення змін до деяких законодавчих актів щодо деяких питань спадкування: Закон України від 20.10.2014 р. № 1709-VII. Відомості Верховної Ради України. 2015. № 1. Ст. 2: [Електронний ресурс]. - Режим доступу: http:// www.zakon.rada.gov.ua/laws/show/1709-18, вільний.

9. Про нотаріат: Закон України від 02.09.1993 р. № 3425-XII: [Електронний ресурс]. - Режим доступу: http:// www.zakon.rada.gov.ua/laws/show/3425-12, вільний.

10. Про державну реєстрацію речових прав: Закон України № 2375-IV від 20.01.2005: [Електронний ресурс]. - Режим доступу: http://www.zakon.rada.gov.ua/go/1952-15.

11. Постанова Верховного Суду України від 23.11.2016 р. у справі № 6-3113цс15: [Електронний ресурс]. - Режим доступу: http://www.search.ligazakon.ua/i_doc2.nsf/link1/vs161119.html.

12. Про фермерське господарство: Закон України від 19.06.2003 p. Відомості Верховної Ради України. 2003. № 45. Ст. 363. [Електронний ресурс]. - Режим доступу: http:// www.zakon.rada.gov.ua/laws/show/973-15, вільний.

13. Про забезпечення прав і свобод громадян та правовий режим на тимчасово окупованій території України: Закон України № 1207-VII від 15.04.2014 року: [Електронний ресурс]. - 
Новітні досягнення та вектори розвитку сучасної юриспруденції

Режим доступу: http://www.zakon.rada.gov.ua/go/1207-18, вільний.

14.Про судову практику розгляду цивільних справ про спадкування: Лист Вищого спеціалізованого суду України 3 розгляду цивільних і кримінальних справ від 16.05 .2013 р. № 24-753/0/4-13. [Електронний ресурс]. - Режим доступу: http//vp.su.court.gov.ua/sud1803/info_gromad/316839.

15. Про Державний земельний кадастр: Закон України від 7 липня 2011 р. № 3613-VI. Відомості Верховної Ради України. 2012. № 8. Ст. 61.

16.Уразовська О.С. Оформлення спадщини на земельну ділянку: особливості та законодавчі новели. Науковий вісник Херсонського державного університету. 2014. Випуск 5. C. 238-243.

17. Наказ Міністерства юстиції України від 22.02.2012 № 296/5: [Електронний ресурс]. - Режим доступу: http:// www.zakon.rada.gov.ua/go/z0282-12, вільний.

18. Осичнюк $Є$. Проблемні питання у спадкуванні нерухомого майна. Електронний журнал. Приватний підприємець. 2013. [Електронний ресурс]. - Режим доступу: http://www.blog.liga.net/ user/eosychnyuk/article/12014.aspx, вільний.

19.Уразовська О.С. Спадкування земельної ділянки іноземними громадянами та особами без громадянства. Правові засоби забезпечення та захисту прав людини: вітчизняний та зарубіжний досвід: матеріали міжнародної науково-практичної конференції, Харків, 21-22 листопада 2014 р. Харків: Асоціація аспірантів-юристів, 2014. С. 90-93.

20.Уразовская 0.С. Коллизионные и проблемные аспекты принятия наследства на землю по законодательству Украины. Legea si viata. Випуск 4/4 (280). Republica Moldova, 2015. C. 103-107. 